THE CHRISTIANS AS THE ROMANS SAW THEM 
This page intentionally left blank 


\section{THE CHRISTIANS}

AS THE ROMANS

SAW THEM

SECOND EDITION

ROBERT LOUIS WILKEN

YALE UNIVERSITY PRESS

NEW HAVEN AND LONDON 
First published by Yale University Press in 1984 .

Copyright $(2003$ by Yale University.

Al rights reserved. This book may not be reproduced, in whole or in part, including illustrations, in any form (beyond that copying permitted by Sections 107 and 108 of the U.S. Copyright Law and except by reviewers for the public press), without written permission from the publishers.

For information about this and other Yale University Press publications, please contact:

U.S.Office sales.press@yale.edu

Europe Office sales@yaleup.co.uk

Printed in the United States of America

Library of Congress Control Number: 2002113908

ISBN 978-0-300-09839-6 (pbk.)

A catalogue record for this book is available from the British Library.

$\begin{array}{llllll}10 & 9 & 8 & 7 & 6 & 5\end{array}$ 
To Don and Mary-

And to summers on Schoodic Lake 
This page intentionally left blank 